\title{
PERAN KEPALA DISTRIK DALAM MENGOPTIMALKAN PENYELENGGARAAN PEMERINTAHAN KELURAHAN PADA DISTRIK MALADOM MES KOTA SORONG
}

\author{
Vinsentya N.S Timisela
}

vinsentya.timisela@gmail.com

\section{Dosen Universitas Victory Sorong- Indonesia}

\begin{abstract}
Abstrak
Penelitan dengan judul “ Peran Kepala Distirk Dalam Mengoptimalkan Penyelenggaraan Pemerintahan Kelurahan Pada Distrik Maladom Mes Kota Sorong" dilakukan untuk mendapatkan gambaran tentang peran Kepala Distrik Maladom Mes Kota Sorong dalam mengoptimalkan pelaksanaan pemerintahan di keempat kelurahan di wilayah Distrik Maladom Mes dalam hal tertib administrasi, dan tertib aparat kelurahan. Penelitian ini dilakukan dengan menggunakan metode deskriptif dengan pendekatan kualitatif, melalui observasi lapangan, studi dokumen, dan wawancara yang melibatkan 6 (enam) informan yang dipilih sebagai sampel penelitian dengan teknik purposive sampling.

Penelitian ini menemukan bahwa peran sebagai pembina dan pengawas penyelenggaraan pemerintahan pada keempat kelurahan di Distrik Maladom Mes yang dijalankan oleh Kepala Distrik dapat mengoptimalkan penyelenggaraan pemerintahan di keempat kelurahan dalam hal peningkatan tertib administrasi, disiplin pegawai, keteraturan koordinasi, dan peningkatan pelayanan publik. Saran penelitian ini bagi Pemerintah Distrik Maladom Mes adalah perlu diadakannya suatu kegiatan pelatihan atau pembinaan di tingkat Distrik secara berkala, berkesinambungan dan teratur tentang tata kelola kearsipan dengan cara pemutakhiran data dan informasi pemerintahan untuk dilakukan sehingga dapat menunjang fungsi kelurahan sebagai basis data kependudukan di jenjang pemerintahan yang lebih tinggi.
\end{abstract}

\section{Kata Kunci : Kepala Distrik, Penyelenggaraan Pemerintahan}

\begin{abstract}
The research focused on "District Head's Role to Optimize The Administrative Village Government in Maladom Mes District Sorong" is done to get the qualitative description about the role of the District Head to put the administration and the officials in order. It is done in descriptive qualitative approach through interview and field observation involving some informants which are taken purposively. The result of the analysis shows that as the supervisor and as the leade, the head of Maladom Mes District has been able to optimize the implementation of government to put the administration and lead the officials in four villages in his authority in order, to lead the coordination and optimize the public service. The research then advising the government to do a
\end{abstract}


training to train documentary and data up dating to the officials to increase the performance.

Keywords: The Head of District's Role. Government Implementation.

\section{PENDAHULUAN}

Pembagian kekuasaan dan wewenang secara hirarkis dalam tata pemerintahan di Indonesia berpayungkan Undang-Undang Nomor 23 Tahun 2014 tentang Pemerintahan Daerah sangat mengedepankan koordinasi dan komunikasi sebagai penghubung setiap jenjang pemerintahan yang berbeda. Dengan demikian kesenjangan antara tiap jenjang pemerintahan tidak terjadi melainkan semakin erat tanpa ada penerapan absolute power atau kekuasaan absolut. Sebagai suatu sistem yang saling terhubung, setiap jenjang pemerintahan yang lebih tinggi menjadi penyelenggara koordinasi terhadap beberapa jenjang pemerintahan di bawahnya, dan jenjang-jenjang pemerintahan yang lebih rendah itu harus bertanggung jawab kepada jenjang di atasnya. Seluruh sistem dan tatanan yang hirarkis tersebut disebut sebagai sistem birokrasi.

Salah satu jenjang pemerintahan sebagaimana dimaksud di atas adalah Kecamatan atau Distrik yang dikepalai oleh seorang Kepala Kecamatan yang disebut juga Camat atau seorang Kepala Distrik. Kecamatan atau Distrik (selanjutnya digunakan istilah Distrik dalam penelitian ini) merupakan unsur pelaksana bidang pemerintahan, pelayanan umum, pembangunan, dan pemberdayaan masyarakat, dipimpin oleh Kepala Distrik yang berkedudukan di bawah dan bertanggung jawab kepada Kepala Daerah Tingkat II yaitu Bupati/Walikota melalui Sekretaris Daerah, serta membawahi beberapa Kelurahan. Untuk itu fungsi koordinatif dan komunikatif juga turut dijalankan untuk menghubungkan jenjang Daerah Tingkat II di atasnya dan kelurahankelurahan di bawahnya.

Distrik Maladom Mes merupakan salah satu Distrik di Kota Sorong yang mengemban tugas melaksanakan kewenangan otonomi daerah berdasarkan azas otonomi dan tugas pembantuan yang diberikan oleh Pemerintah Pusat dan Pemerintah Provinsi Papua Barat melalui Pemerintah Kota Sorong. Peraturan Daerah Kota Sorong Nomor 5 tahun 2010 tentang Organisasi dan Tata Kerja 
Distrik dan Kelurahan Kota Sorong Pasal 3 Ayat (3) huruf f, seorang Kepala Distrik bertanggung jawab menyelenggarakan tugas umum yaitu membina penyelenggaraan pemerintahan Kelurahan. Kata membina mengandung suatu perintah pengawasan, memelihara dan memastikan seluruh proses berjalan dengan baik. Sedangkan menurut penjelasan Perda tersebut, membina penyelenggaraan pemerintahan kelurahan meliputi:

a) Melakukan pembinaan dan pengawasan tertib administrasi pemerintahan Kelurahan

b) Memberikan bimbingan, supervisi, fasilitasi, dan konsultasi pelaksanaan administrasi kelurahan

c) Melakukan pembinaan dan pengawasan terhadap Kepala Kelurahan

d) Melakukan pembinaan dan pengawasan terhadap perangkat kelurahan

e) Melakukan evaluasi penyelenggaraan pemerintahan kelurahan di tingkat Distrik

f) Melaporkan pelaksanaan pembinaan dan pengawasan penyelenggaraan pemerintahan kelurahan di tingkat Distrik kepada Walikota Sorong.

Distrik Maladom Mes membawahi 4 (empat) Kelurahan, yaitu : Kelurahan Saoka,Kelurahan Tanjung Kasuari, Kelurahan Suprau dan Kelurahan Tampa Garam. Dalam observasi awal penelitian terhadap penyelenggaraan pemerintahan di keempat kelurahan didapati ketidaktertibannya administrasi kependudukan, minimnya tata kearsipan dan surat menyurat, tidak adanya dokumentasi notula rapat maupun evaluasi internal kelurahan, maupun ketidakdisiplinan perangkat kelurahan dalam kehadirannya di kantor lurah. Sedangkan observasi terhadap dokumen kepegawaian di keempat kelurahan menemukan rendahnya manajemen sumber daya manusia pada perangkat kelurahan yang disebabkan oleh tidak meratanya keahlian dan latar belakang pendidikan dari perangkat kelurahan untuk menduduki jabatan-jabatan struktural. Data awal ini mengindikasikan belum optimalnya penyelenggaraan pemerintahan di kelurhan-kelurahan pada Distrik Maladom Mes. 
Dalam kaitan dengan tugas dan fungsi Pemerintah Distrik dibawah pimpinan Kepala Distrik sesuai dengan Perda Kota Sorong No.5 Tahun 2010, maka peran dari Kepala Distrik dalam membina dan mengawasi penyelenggaraan pemerintahan kelurahan sangat diperlukan untuk mengevaluasi dan mengambil kebijakan atau merumuskan solusi guna pengoptimlan penyelenggaraan pemerintahan di tiap kelurahan di wilayahnya.

\section{TINJAUAN PUSTAKA}

\section{Teori Birokrasi Weber}

Teori birokrasi Max Weber (Thoha,2005) menjadi dasar bagi praktek pemerintahan yang dijalankan dalam suatu sistem birokrasi atau administrasi kenegaraan. Teori yang dikenal juga dengan teori Birokrasi Weberian ini menggambarkan tipe birokrasi ideal dari suatu organisasi rasional dan efisien yang menjadi bagian dari dominasi legal.

Menurut Weber (Thoha,2005:16) tipe ideal birokrasi yang rasional itu dilakukan dalam cara-cara sebagai berikut:

a) Pejabat secara rasional bebas, menjalankan jabatan dan wewenangnya

b) Jabatan disusun oleh tingkat hirarki dari atas ke bawah dan kesamping dengan konsekuensinya berupa perbedaan kekuasaan

c) Tugas dan fungsi masing-masing jabatan dalam hirarki secara spesifik berbeda satu sama lain

d) Setiap pejabat mempunyai kontrak jabatan yang harus dijalankan

e) Setiap pejabat diseleksi atas dasar kualifikasi profesionalitasnya

f) Setiap pejabat mempunyai gaji termasuk hak untuk menerima pensiun

g) Terdapat struktur pengembangan karier yang jelas

h) Setiap ejabat sama sekali tidak dibenarkan menjalankan jabatannya untuk kepentingan pribadi

i) Setiap pejabat berada di bawah pengendalian dan pengawasan suatu sistem yang dijalankan secara disiplin.

Dalam pemerintahan, kekuasaan publik dijalankan oleh pejabat pemerintah atau para birokrat yang melaksanakan tugasnya sesuai dengan peran dan fungsiya dalam sistem birokrasi negara dan harus mampu mengendalikan orang-orang yang dipimpin. Birokrasi dalam hal ini memiliki tiga arti, yaitu: 
a) Sebagai tipe organisasi yang khas

b) Sebagai suatu sistem (struktur)

c) Sebagai suatu tatanan jiwa tertentu dan alat kerja organ negara untuk mencapai tujuannya (Sinambela, 2006:65)

Dalam negara administratif, pemerintah dan seluruh jajarannya dikenal sebagai abdi masyarakat dalam pemberian berbagai jenis pelayanan yang dibutuhkan oleh seluruh warga masyarakat. Keseluruhan jajaran pemerintahan negara merupakan suatu birokrasi pemerintahan yang juga dikenal dengan istilah civil service. Pemerintah beserta seluruh jajaran aparatur birokrasi bukanlah satusatunya pihak yang bertanggung jawab untuk menyelenggarakan berbagai kegiatan pembangunan nasional, tetapi merupakan kenyataan bahwa peranan pemerintah dan jajarannya bersifat dominan.

Model birokrasi yang ideal bukan bertumpu pada kultur semata, tetapi juga bertumpu pada profesionalisme birokrasi, terutama aparat birokrasinya. Profesionalisme birokrasi ini terfokus pada adanya penjenjangan struktur secara tertib dengan pendelegasian wewenang, posisi jabatan dan tugas-tugas, dan aturan-aturan yang jelas, serta tersedianya personil yang memiliki kecakapan dan kredibilitas yang memadai dalam bidang tugasnya.

Beberapa pemikiran Weber yang ditegaskan dalam teori birokrasinya adalah:

a) Birokrasi harus dioperasikan dalam suatu sistem hirarki vertikal yang ketat dan komunikasi antar pekerja dibatasi sesuai jabatannya.

b) Birokrasi harus menerapkan pembagian kerja, dimana setiap jabatan memiliki spesifikasi kerja yang berbeda

c) Alur kekuasaan dalam suatu birokrasi harus terpusat. Manajemen pusat memiliki kontrol terhadap proses pengambilan keputusan dan kegiatan pekerja

d) Sistem birokrasi harus merupakan suatu sistem tertutup

e) Peraturan yang tertulis sangat penting bagi organisasi yang menjalankan birokrasi agar pekerjaan dapat berjalan dengan teratur dan formal

f) Menganut tiga fungsi kekuasaan (functioning of authority), yaitu:

- Traditionally Authority, yaitu kekuasaan yang berasal dari kepercayaan secara tradisional 
- Charismatic Authority, yakni kekuasaan yang berdasarkan kemampuan seseorang untuk berinteraksi atau menarik hati orang lain. Kekuasaan tipe ini sangat tidak stabil

- Rational-legal Authority, kekuasaan yang didapatkan dari kemampuan individu. Weber sangat menekankan pada kekuasaan tipe ini, karena menurutnya ini adalah dasar dari functioning authority.

\section{Teori Kekuasaan sebagai Landasan dari Peranan dan Pengaruh Seorang Pemimpin.}

Konsep kekuasaan (power) erat sekali hubungannya dengan konsep kepemimpinan. Dengan kekuasaan pemimpin memperoleh alat untuk mempengaruhi perilaku para pengikut, bawahan atau pegawainya. Hersey, Blanchard dan Natemeyer dalam Thoha (2010:329) berpendapat bahwa para pemimpin seharusnya tidak hanya menilai perilakunya sendiri, agar mereka dapat mengerti bagaimana mereka mempengaruhi orang lain sambil meniti posisi dan cara mereka menggunakan kekuasaannya ${ }^{16}$.

Pelopor utama dalam penggunaan istilah kekuasaan adalah Max Weber yang kemudian diperjelas oleh M.F. Rogers dengan merumuskan kekuasaan sebagai suatu "potensi dan suatu pengaruh". Dengan demikian, kekuasaan adalah suatu sumber yang bisa atau tidak bisa digunakan. Dikatakan oleh Rogers bahwa penggunaan kekuasaan selalu menimbulkan perubahan dan perubahan itu disebutnya "pengaruh" (influence), pengaruh merupakan kemampuan untuk mempengaruhi karena kekuasaan yang dimiliki oleh seseorang. Dihubungkan dengan konsep kepemimpinan sebagai suatu proses untuk mempengaruhi aktivitas-aktivitas individu atau kelompok dalam usahanya untuk mencapai tujuan dalam situasi tertentu, maka kekuasaan merupakan potensi pengaruh dari seorang pemimpin. Tanpa kekuasaan, potensi mempengaruhi seorang pemimpin akan lebih lemah.

Amitai Etziomi (1961) membagi sumber dan bentuk kekuasaan pada: (1) kekuasaan jabatan (position power), yaitu kemampuan seseorang untuk

Paul Hersey dan Kenneth Blanchard, Management of Organizational Behaviour, Utilizing
Human Resource, Engelwood Cliffs, New jersey. 1982. Hlm. 151-155. 
mempengaruhi perilaku orang lain untuk melakukan kerja karena jabatan organisasi yang dijabatnya, dan (2) kekuasaan pribadi (personal power) yaitu kekuasaan yang diperoleh seseorang dari pengikutnya sehingga ia dapat mempengaruhi mereka ${ }^{17}$. Pendapat Etziomi ini kemudian dikembangkan oleh para ahli lain yang pada akhirnya merumuskan tujuh sumber dan bentuk kekuasaan sebagai berikut:

a. Kekuasaan Paksaan (Coercive Power).

Kekuasaan ini berdasarkan dan bersumber pada rasa takut para pengikut atau bawahan atau pegawai kepada pimpinannya yang memiliki kemampuan untuk mengenakan hukuman yang bersifat fisik.

b. Kekuasaan Legitimasi (Legitimate Power).

Kekuasaan ini bersumber pada jabatan yang dipegang oleh pimpinan. Semakin tinggi jabatan/posisi seorang pemimpin, maka semakin besar pula kekuasaan legitimasinya, karena wewenang pemimpin tingkat atas semakin besar yang kemudian terurai oleh pendelegasian sebagian wewenangnya kepada pemimpin di bawahnya.

c. Kekuasaan Keahlian (Expert Power).

Kekuasaan ini bersumber pada keahlian atau kecakapan atau pengetahuan yang dimiliki oleh seorang pemimpin yang diwujudkan lewat rasa hormat, rasa segan dan pengaruh terhadap orang lain karena semakin tinggi keahlian atau pengetahuannya semakin besar potensi mempengaruhi orang lain.

d. Kekuasaan Penghargaan (Reward Power).

Kekuasaan ini bersumber pada kemampuan untuk menyediakan penghargaan atau hadiah bagi orang lain, seperti gaji, promosi atau penghargaan jasa. Kekuasaan ini juga berhubungan dengan kebutuhan orang-orang yang dipimpin akan penghargaan atau hadiah yang disediakan pimpinan.

e. Kekuasaan Referensi (Referent Power).

Kekuasaan ini bersumber pada sifat-sifat pribadi dari seorang pemimpin. Pemimpin dengan kekuasaan referensi yang semakin tinggi semakin disenangi dan dikagumi oleh orang lain karena kepribadiannya.

f. Kekuasaan Informasi (Information Power).

Kekuasaan ini bersumber pada ekses informasi yang dimilki oleh pemimpin yang dinilai sangat berharga oleh pengikutnya. Kekuasaan ini timbul karena kebutuhan akan informasi yang dimiliki pimpinan yang dapat mempengaruhi orang lain. Sebagai contoh seorang pimpinan memiliki potensi mempengaruhi seorang bawahannya jika ia memiliki informasi yang mengikat bawahannya tersebut, entahkan

17 Amitai Etziomi, A Comparative Analysis of Complex Organization, New York, The Free Press. 1961. 
tentang organisasi sehingga berhubungan dengan kerja dan tugas bawahannya atau mungkin saja informasi pribadi si bawahan yang tak diinginkannya untuk diketahui orang lain, sehingga si bawahan dapat dipengaruhi oleh pimpinannya tersebut.

g. Kekuasaaan Hubungan (Connection Power).

Kekuasaan ini bersumber pada hubungan yang dijalin oleh pimpinan dengan orang-orang penting dan berpengaruh lainnya baik di dalam organisasi yang dipimpinnya maupun di luar organisasi ${ }^{18}$.

Ketujuh sumber dan bentuk kekuasaaan sebagaimana yang dipaparkan Thoha di atas dalam kaitannya dengan gaya kepemimpinan seorang pemimpin dapat digambarkan hubungan aplikasinya sebagai berikut:

a. Pimpinan yang memiliki sumber kekuasaan paksaan biasanya menerapkan gaya kepemimpinan yang suka memerintah atau memberi instruksi. Kekuasaan paksaan yang dimiliki pimpinan dapat dipergunakan untuk memotivasi bawahan untuk menghindari hukuman atau sanksi dengan cara mematuhi apa yang dikatakan pimpinan.

b. Dalam kekuasaan hubungan, maka gaya kepemimpinan yang cocok diterapkan adalah gaya kepemimpinan instruksi dan konsultasi.

c. Pimpinan yang kekuasaannnya bersumber dan berbentuk kekuasaan penghargaan cocok menerapkan gaya kepemimpinan konsultasi.

d. Pimpinan dengan sumber dan bentuk kekuasaan legitimasi sangat cocok dan biasanya menerapkan gaya kepemimpinan partisipasi dan konsultasi.

e. Dalam kekuasaan yang bersumber pada referensi maka gaya kepemimpinan partisipasi dapat mengefektifkan kepemimpinannya.

f. Pada kekuasaan Informasi, gaya kepemimpinan yang cocok dan efektif diterapkan adalah gaya kepemimpinan partisipasi dan delegasi.

g. Dan untuk kekuasaan keahlian, maka gaya kepemimpinan yang cocok diterapkan adalah gaya kepemimpinan delegasi.

\section{Konsep Peran}

Peran berkaitan erat dengan individu, lembaga maupun organisasi dalam usahanya untuk menjalankan fungsinya masing-masing. Kamus Besar Bahasa Indonesia mengartikan peran sebagai tugas utama yang dilaksanakan. Sedangkan Soerjono Soekamto (2010) dalam bukunya Sosiologi Suatu Pengantar

18 Miftah Thoha, Perilaku Organisasi: Konsep Dasar dan Aplikasinya, PT. RajaGrafindo Persada, Jakarta, 2010. Hlm. 334-340. 
mengartikan peran sebagai " aspek dinamis dari kedudukan, status, apabila seseorang melakukan hak-hak dan kewajiban sesuai dengan kedudukannya”. Dalam buku yang sama Soekamto mengutip Ralph Uton yang menyatakan bahwa peranan harus mencakup tiga hal berikut:

a. Peranan harus meliputi norma-norma yang dihubungkan dengan posisi (tempat, kedudukan) seseorang dalam masyarakat.

b. Peranaan adalah suatu konsep perihal apa yang dapat dilakukan individu dalam masyarakat sebagai suatu organisasi.

c. Peranan juga dapat dikatakan sebagai perilaku individu yang penting bagi struktur sosial.

Berdasarkan jabaran pengertian dan cakupan peran di atas disimpulkan bahwa peranan merupakan tugas utama yang dilakukan individu, kelompok, lembaga atau organisasi dalam masyarakat dan yang merupakan bagian dari mayarakat itu yang memenuhi konsep perihal apa yang dapat dilakukan untuk memenuhi tujuannya bertugas.

\section{Peran Kepala Distrik dalam Penyelenggaraan Pemerintahan di Kelurahan}

Berdasarkan Peraturan Daerah Kota Sorong Nomor 5 Tahun 2010, tentang Organisasi dan Tata Kerja Distrik dan Kelurahan Kota Sorong, maka tugas dan fungsi Kepala Distrik adalah sebagai berikut:

a. Kepala Distrik mempunyai tugas dan fungsi melaksanakan sebagian urusan Otonomi Daerah yang dilimpahkan oleh Walikota;

b. Pelimpahan urusan Otonomi Daerah sebagaimana dimaksud pada ayat (1) diatur dalam Peraturan Walikota

c. Kepala Distrik juga wajib menyelenggarakan tugas umum pemerintahan meliputi:

1) Mengkoordinasikan kegiatan pemberdayaan masyarakat;

2) Mengkoordinasikan upaya penyelenggaraan ketentraman dan ketertiban umum;

3) Mengkoordinasikan penerapan dan penegakkan peraturan perundang-undangan;

4) Mengkoordinasikan pemeliharaan prasarana dan fasilitas umum;

5) Mengkoordinasikan penyelenggaraan pemerintahan di tingkat distrik;

6) Membina penyelenggaraan pemerintahan kelurahan 
7) Melaksanakan pelayanan masyarakat yang menjadi ruang lingkup tugas dan/atau yang belum dapat dilaksanakan oleh pemerintah kelurahan.

Berkaitan dengan fokus penelitian dan masalah yang dikaji dalam penelitian ini maka tinjauan tugas dan peran Kepala Distrik dikhususkan pada tugas membina penyelenggaraan pemerintahan kelurahan yang meliputi:

a. Pembinaan dan pengawasan tertib administrasi pemerintahan kelurahan;

b. Memberikan bimbingan, supervisi, fasilitasi, dan konsultasi pelaksanaan administrasi kelurahan;

c. Pembinaan dan pengawasan terhadap Kepala Kelurahan;

d. Pembinaan dan pengawasan terhadap perangkat kelurahan;

e. Mengevaluasi penyelenggaraan pemerintahan kelurahan di tingkat Distrik;

f. Melaporkan pelaksanaan pembinaan dan pengawasan penyelenggaraaan pemerintahan kelurahan di tingkat Distrik kepada Walikota.

\section{METODE PENELITIAN}

Penelitian ini dilakukan di Wilayah Kerja Distrik Maladom Mes Kota Sorong Provinsi Papua Barat yang meliputi empat wilayah Kelurahan yang dibawahinya yakni Kelurahan Saoka, Kelurahan Tampa Garam, Kelurahan Tanjung Kasuari dan Kelurahan Suprau yang berpusat pada Kantor Distrik Maladom Mes sebagai unit kerja dari Kepala Distrik yang menjadi objek utama penelitian ini.Dengan pendekatan deskriptif kualitatif dan pengambilan sampel penelitian secara purposive sampling.

\section{HASIL DAN PEMBAHASAN}

1. Peran Kepala Distrik dalam Pembinaan dan Pengawasan Tertib Administrasi Pemerintahan Kelurahan

Tertib administrasi dalam pemerintahan kelurahan berkaitan erat dengan administrasi kependudukan dan pencatatan sipil (Admindukcapil) dimana 
kelurahan menjadi sumber utama dari informsi kependudukan bagi jenjang pemerintahan di atasnya. Oleh karena itu tertib administrasi harus dimulai dari kelurahan sebagai bank informasi kependudukan dari masyarakat yang berada di wilayah pemerintahannya. Berkaitan dengan peran Kepala Distrik sebagai pembina dan pengawas tertib administrasi di tingkat kelurahan telah dilakukan wawancara dan observasi lapangan tentang pelaksanaannya di Distrik Maladom Mes Kota Sorong. Dari 5 (lima) informan kunci yakni: Bapak Fillip Karubaba, S.STP selaku Kepala Distrik Maladom Mes, dan 4 (empat) lurah di distrik Maladom Mes, masing-masing Lurah Saoka Bapak Frans Kalasuat, Lurah Tampa Garam Ibu Dorce Jitmau,S.IP, Lurah Suprau Bapak Frengky Mayor, dan Lurah Tanjung Kasuari Bapak Olof Burdam,S.IP dalam wawancara yang dilakukan di ruang kerja masing-masing informan pada tanggal 8-10 Agustus 2018 dirangkum deskripsi wawancara sebagai berikut:

a. Bahwa guna mendapatkan informasi Dukcapil terkini dan memastikan tertibnya penyelenggaraan Admindukcapil pada setiap kelurahan di Distrik Maladom Mes maka Kepala Distrik berkebijakan untuk:

1. Mengadakan rapat pimpinan kelurahan sebulan sekali guna mendiskusikan masalah-masalah administrasi yang mungkin muncul sekaligus melakukan koordinasi pelaksanaan program sebulan.

2. Mengadakan pelatihan administrasi dan kearsipan kepada perangkat kelurahan dengan bekerjasama dengan Perguruan Tinggi swasta di Kota Sorong.

3. Mengagendakan penambahan sarana administrasi berupa komputer serta pemeliharaannya dan fasilitas kearsipan seperti lemari arsip dan sebagainya di setiap tahun anggaran.

4. Melakukan supervisi secara teratur ke setiap kelurahan untuk memastikan tertibnya pelaksanaan administrasi di tiap kelurahan serta disiplin kehadiran perangkat kelurahan.

b. Dari keempat Lurah di Distrik Maladom Mes diperoleh informasi bahwa kehadiran Kepala Distrik pada setiap kunjungannya ke Kelurahan lebih bernuansa mengayomi dan membina serta selalu memberikan kesempatan 
kepada Lurah maupun staf kelurahan untuk mengkonsultasikan masalahmasalah pelayanan masyarakat maupun program-program yang sementara dilaksanakan.

c. Bahwa keempat Lurah memberikan apresiasi positif terhadap kecakapan dan kepantasan Kepala Distrik yang meskipun jauh lebih muda dari para Lurah namun dapat menempatkan diri sebagai pimpinan yang bijak. Sebagai seorang Sarjana Ilmu Pemerintahan dari Kepala Distrik para Lurah berkesempatan belajar baik tentang ilmu pemerintahan maupun tentang bagaimana membangun tim kerja yang efisien dan efektif serta kedisiplinan beradministrasi. Sehingga kehadiran seorang Kepala Distrik di tingkat kelurahan seperti ini justru memberi semangat dan dukungan moril bagi perubahan pemerintahan ke arah yang lebih baik.

\section{Peran Kepala Distrik dalam Pembinaan dan Pengawasan terhadap Kepala dan Perangkat Kelurahan}

Berkenan dengan peran Kepala Distrik dalam membina dan mengawasi kinerja dari Lurah maupun perangkat kelurahan di Distrik Maladom Mes, peneliti telah melakukan observasi lapangan baik di Kantor Distrik maupun di Kantor Kantor Kelurahan dan data observasi memberikan gambaran tentang pembinaan dan pengawasan yang dilakukan Kepala Distrik Maladom Mes sangat ramah dan membangun meskipun dalam teguran yang tegas sekalipun. Hal ini pun tergambar dalam hasil wawancara dengan Sekretaris Distrik Maladom Mes maupun keempat Lurah. Kelima informan sependapat bahwa mereka dalam interaksi pengawasan tidak merasa sedang diawasi dan ketika ada kesalahan, kelalaian ataupun ketidakdisiplinan Kepala Distrik selalu menegur di bawah empat mata sehingga yang ditegur tidak merasa minder di hadapan rekan kerja maupun masyarakat dan suasana kerja tetap terpelihara serta oknum yang ditegur tidak kehilangan rasa percaya diri dan merasa tetap dihargai.

Dari wawancara dengan Kepala Distrik sendiri peneliti mendapatkan kejelasan bahwa ia memahami perannya sebagai pengawas kinerja pegawai/ bawahannya sebagai sarana memastikan berjalannya pemerintahan dan pelayanan 
publik yang berkualitas sebagaimana visi Distrik Maladom Mes. Dan menurutnya meskipun pengawasan harus dilakukan seramah mungkin namun harus tegas dan tidak diskriminan bahkan pimpinan dalam kapasitasnya sebagai pengawas harus menjadi teladan bagi bawahaannya. Jika pimpinan disiplin dengan dirinya sendiri maka bawahan akan sadar akan ketidakdisiplinannya. Itu cara menegur yang paling ramah. Itu yang namanya membina, sebab membina berarti memelihara keberlangsungan suatu hal yang baik bukan memastikan terlaksananya sesuatu ketika diawasi saja. Budaya pengawasan ini menurut para Lurah telah mengubah suasana kerja di masing-masing kelurahan yang mereka pimpin. Kantor kosong tanpa perangkat kelurahan sekarang menjadi hal yang tidak lagi dapat ditemui, dokumentasi kearsipan semakin teratur serta pelayanan publik dalam hal admindukcapil berjalan dengan lebih teratur dan lancar.

Visi Distrik Maladom Mes yaitu "Terwujudnya Pemberdayaan Masyarakat Yang Maju, Mandiri, Sejahtera" menurut Kepala Distrik Maladom Mes adalah visi dari semua kelurahan di wilayah Distrik Maladom Mes. Yang harus mewujudkannya adalah perangkat Distrik dan Kelurahan sebagai penyelenggara pemerintahan sesuai porsinya. Untuk mewujudkannya maka ada misi yang harus dilakukan terlebih dahulu. Misi-misi ini harus diawasi pelaksanaan maupun penyelenggaraannya sehingga visi tidak hanya menjadi slogan tetapi menjadi cita-cita yang menjadi kenyataan. Oleh karena itu baik pimpinan sebagai pengawas maupun perangkat distrik dan kelurahan sebagai penyelenggara misi harus mengusahakan perubahan dari kesalahan, ketidakdisiplinan, ketidakteraturan dan ketidaktertiban yang ada menjadi apa yang dicita-citakan dalam visi dan misi Distrik Maladom Mes. Jadi perubahan ke arah yang lebih baik menjadi suatu keharusan dan harus menjadi agenda utama setiap perangkat pemerintahan di keluraha maupun distrik.

Mengusik masalah komunikasi dalam koordinasi yang dibangun oleh Kepala Distrik dengan bawahannya di Distrik maupun dengan perangkat kelurahan keenam informan memberikan ulasan yang sama. Mereka berpendapat bahwa komunikasi yang terbangun merupakan komunikasi yang tidak mementingkan prosedur protokoler sehingga koordinasi baik koordinasi 
horizontal maupun vertikal yang melibatkan Kepala Distrik dalam menjalankan tugas dan fungsi pembinaan dan pengawasan penyelenggaraan pemerintahan di setiap kelurahan di Distrik Maladom Mes sangat efisien dan tepat pada sasaran sehingga selalu berhasil memecahkan masalah yang dihadapi atau yang sementara dikoordinasikan.

\section{Kesimpulan}

Dari uraian di atas dapat disimpulkan bahwa Kepala Distrik Maladom Mes Kota Sorong telah dapat menjalankan perannya sebagai pembina dan pengawas penyelenggaraan pemerintahan pada kelurahan-kelurahan yang berada di bawah wewenangnya sebagai tanggung jawabnya atas wewenang yang diberikan Walikota Sorong. Bahwa kepemimpinan seorang Kepala Distrik dalam penelitian ini dibuktikan mempengaruhi penyelenggaraan pemerintahan di kelurahankelurahan di wilayah Distrik Maladom Mes sehingga pelayanan publik dapat terlaksana dengan lebih baik sebagai akibat dari perbaikan disiplin perangkat kelurahan, penaraan administrasi kependudukan yang diarsipkan dengan lebih baik.

Hasil penelitian ini juga menemukan bahwa Kepala Distrik Maladom Mes Kota Sorong dalam menjalankan perannya sebagai pimpinan telah memberikan teladan dan contoh yang baik bagi bawahannya baik di Kantor Distrik Maladom Mes sendiri maupun kepada perangkat kelurahan di keempat kelurahan yang dibawahinya. Komunikasi koordinasi yang terbangun dalam peran Kepala Distrik juga terbukti mempengaruhi pengoptimalan kinerja kelurahan. Meskipun demikian ketegasan dan penegakan disiplin tetap menjadi hal utama. Seluruh peran yang telah dijalankan Kepala Distrik Maladom Mes memberi pengaruh yang besar pada pemenuhan visi Distrik Maladom Mes berikut seluruh misi jabarannya.

Selain itu peran sebagai pembina dan pengawas penyelenggaraan pemerintahan pada keempat kelurahan di Distrik Maladom Mes yang dijalankan oleh Kepala Distrik telah dapat mengoptimalkan penyelenggaraan pemerintahan 
di keempat kelurahan dalam hal peningkatan tertib administrasi, disiplin pegawai, keteraturan koordinasi, dan peningkatan pelayanan publik.

Bertolak dari hasil penelitian ini maka peneliti berkesempatan untuk memberikan masukan Kepada Pemerintah Distrik Maladom Mes untuk mengadakan suatu kegiatan pelatihan atau pembinaan di tingkat Distrik secara berkala, berkesinambungan dan teratur tentang tata kelola kearsipan dengan cara pemutakhiran data dan informasi pemerintahan untuk dilakukan sehingga dapat menunjang fungsi kelurahan sebagai basis data kependudukan di jenjang pemerintahan yang lebih tinggi.

\section{DAFTAR PUSTAKA}

Amitai Etziomi, A Comparative Analysis of Complex Organization, New York, The Free Press. 1961.

Paul Hersey dan Kenneth Blanchard, Management of Organizational Behaviour, Utilizing Human Resource, Engelwood Cliffs, New jersey. 1982.

Soekamto, Sarjono. 2010. Sosiologi Suatu Pengantar.

Thoha, Miftah. 2005. Birokrasi dan Politik di Indonesia. Cetakan I, PT. Raja Grafindo Persada, Jakarta.

--------. 2010. Perilaku Organisasi; Konsep Dasar dan Aplikasinya. PT. Raja Grafindo Persada. Jakarta.

Albrow, Martin. 1989. Birokrasi. Tirta Wacana, Yogyakarta.

Irwanto. 1998. Focus Group Discussion (FGD), Sebuah Pengantar Praktis. Pusat Kajian Pembangunan Masyarakat, Jakarta.

Kumorotomo, Wahyudi. 2009. Etika Administrasi Negara. PT. RajaGrafindo Persada, Rajawali Press, Jakarta.

Moleong, Lexy J., 1994. Metode Penelitian Kualitatif, PT. Remaja Karya, Bandung

Thoha, Miftah. 2005. Birokrasi dan Politik di Indonesia. Cetakan I, PT. Raja Grafindo Persada, Jakarta. 
Siagian, Sondang P., 2007. Administrasi Pembangunan, Konsep, Dimensi, dan Strateginya. Cetakan ke-7. PT. Bumi Aksara, Jakarta.

Sinambela, Lijan Poltak. 2006. Reformasi Pelayanan Publik. PT. Bumi Aksara, Jakarta. 